\title{
THE PROMONTORY OF CAPE GUARDAFUI
}

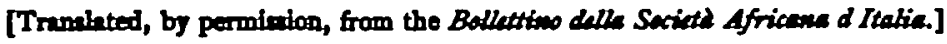

The Italian Protectorate of Northern Somalia consists of the Sultanate of Migiurtina (Mijjertein), handed over by the Convention of April 7th, 1899, the territory of Nogal, acquired by the agreement of May 5th, 1905, and the Sultanate of Obbia, placed under the protection of Italy by the Conventions of February 8th, 1889.

The Sultanate of Migiurtina is on the west conterminous with the country of the Warsangeli and Dolbohanta tribes in British Somaliland, the exact line of delimitation being the meridian of $49^{\circ} \mathrm{E}$. On the south-west it is separated by the Wady Nogal from the territory given to Sayid Muhamad bin Abdullahi, and on the remaining sides it is bounded by the Indian Ocean.

Starting from Bander Ziada, a little to the west of the 49th meridian, the coast runs north-eastward as far as Alula, in lat. ${ }_{11}^{\circ} 53^{\prime} \mathrm{N}$., long. $51^{\circ} \mathrm{O2}^{\prime} \mathrm{E}$. of Greenwich, where it turns E.S.E. as far as $51^{\circ} 18^{\prime} \mathrm{E}$. by $11^{\circ} 50^{\prime} \mathrm{N}$. At this point, turning at a right angle, it forms the promontory of Ras Asir, commonly called Cape Guardafui, a name of ill-omen for all navigators, and prophetic of good fortune to its inhabitants, and then runs almost due south as far as the peninsula of Hafun, where it turns to the south-west.

Bander Ziada, or Hau, the first village of any importance met with on the passage from Aden to the northern coast of the Italian Protectorate, is one of the oldest settlements in Migiurtina. Its foundation goes back to the beginning of the last century, and its first inhabitants were nomads from the interior, who gradually came to live on the sea-shore, attracted 
by the prospect of trade. At present it is inhabited by the Wabenaya, and four or five families of Warsangeli-four or five hundred persons in all. There are two hundred huts and three stone forts (geresa). The present chief of the district is Yusuf Nur, of the Bahadir tribe.

The Daghan, a perennial stream with a strong current during the rainy season, is about three hours distant from Bander Ziada. At one time a settlement was begun near its mouth, but the work of building was interrupted by tribal wars. One ruined house, belonging to Nur Osman ${ }^{1}$ (now dead, uncle and guardian of the present Sultan Osman Mahmud), is all that remains. From this ruin the place is known as El Bet Nur- "the house of Nur." About 3t hours' walk from Bet Nur, we come to Bander Kasnin (so called by the Arabs : the native name is Bosaso), which was built about sixty years ago, the Kaptallah (a seafaring tribe, now almost extinct) being the first to build a few huts there. They were joined, not long after, by the Deshisha. These last were attacked and defeated by the Bagaren, who came down from the interior, envious of the increasing trade and prosperity of the coast, and supplied themselves with arms at Makalla, on the Arabian coast, and with stone and lime (for constructing a fort) at Aden. The Deshisha appealed to Mahmud Yusuf (father of the present Sultan), who, in order to keep the peace, sent down some people of his own tribe (the Bahadir), assigning them a place in which to build their huts and settle. Before the year was out, the Deshisha, smarting under the defeat they had suffered, and eager to revenge themselves, joined forces with the Bahadir, and challenged the Bagaren to combat. The latter, strong in the possession of a fort, were once more victorious.

The Deshisha and their allies, the Bahadir, then saw that they might have a chance of annihilating the power of the Bagaren by striking directly at their chief, Nur Muhammad, a violent and quarrelsome man. They therefore resorted to a stratagem, and summoned the elders of all the tribes to a

2 He me almag houtlle to ws and roold never permit bis nephew to go on board an Italine man-af-war and render homage to the protecting antion. 
conference, in order to discuss the conditions of peace. Nur, who came with the rest, was treacherously murdered, on the very spot where (whether by accident or design) the Bahadir afterwards built their fort, now the usual residence of Ahmed Tajer, the Sultan's brother and Chief of Bosaso.

After this disaster to the Bagaren, the struggle continued, becoming more and more sanguinary, till about twenty years ago, when the combatants came to terms and made peace, one of the conditions being that no member of the Deshisha or the Bagaren tribe should ever be Chief of Bosaso. The peace, however, is continually broken, even in these days, by blood-feuds, originating in rivalries between clans and tribes.

While the struggle was in progress, several Arab families arrived from the island of Socotra, and settled among the local tribes, by mingling with whom they originated a new tribe, called that "of the Arabs," and now occupying the western part of the country.

The most active stage of the war being now past, all the tribes set themselves to constructing forts, of which there are now seven at Bosaso-three belonging to the Bahadir, two to the Deshisha, one to the Bagaren, and one to the Arabs-not counting several others, of smaller size. The Deshisha have asked leave to build another, larger than all the rest, on the high ground inland, but, up to the present time, Sultan Osman has not granted the desired permission. These small forts are used in time of peace to store weapons, ammunition, and provisions under cover, or sometimes as a prison. ${ }^{1}$

Bosaso is situated on the chord of an arc formed by two chains of mountains, starting, the one from Bander Ziada, and the other from Ras Al Amar, east of Bosaso, and meeting at Karin, about six hours' journey from the coast. At their point of junction, the Daghan, its volume increased by numerous brooks, flows through a deep ravine, and, as previously stated, disembogues about three hours from Hau.

Karin is stated by those who have been there (I have never

\footnotetext{
1 Signor Baldecoi's article is illustrated with photographs of three of the Bosaso forts. They are cartellated stone baildings of two stories, pierced with loopholes for masketry : that of the Bagaren appears to be in the beat condition.-Tr.
} 
been able to go myself) to be a place where vegetation is abundant, and this account is confirmed by the fact that all the principal families of Bosaso retire thither during the season of the south-west monsoon, when, as the people say, "the coast is closed." Ahmed Tajer himself has built a small fort there. I have also heard that this year the date-palms planted six years ago have yielded an abundant crop. Other fruits have also done well, among them cocoa-nuts, some of which I have myself tasted when staying at Bosaso.

Karin is the last halting-place for the numerous caravans coming down to the coast (either to Bender Ziada or Bosaso) from Northern Somaliland as far as the Nogal Valley. The greater number of these come to Bosaso, which may be called the key of the whole Somali trade, as shown by the statistical tables at the end of this article.

The chiefs at Bosaso are: For the Deshisha, Fahia Ali and Ali Gurei ; for the Bagaren, Ussen Ali Sadad. These in their turn are subject to the chief of the Bahadir, who, as the Sultan's brother, is supreme chief of the district. The Arabs have no chief of their own, most of them having emigrated to Obbia-I believe on account of the oppression they have suffered at the hands of Ahmed Tajer.

The natives pay no tribute whatever, either on the caravan trade or on that carried on by the sambuks (small coastingvessels); it is paid, however, by the Arabs and Indians, great numbers of whom are engaged in a considerable import and export trade. The payment of customs duties is more or less regulated after the following fashion: $2 \frac{7}{2}$ sacks of rice on every 100; 1 hide out of every bundle of 100 ; I piece of cotton fabric out of every bale of 25 pieces. At one time the import duty on rice amounted to 5 sacks in the 100 , and the chief of the country was bound to protect the traders' property by taking measures to prevent the Beduins of the interior, when driven down to the coast by hunger, from cutting open the sacks piled on the beach in order to get at the rice, which they devoured raw. He could certainly have done this by distributing food on his own account to these poor wretches, but, preferring a smaller and certain profit to the expense and trouble of these precautions, he decided on reducing the duty 
by half, while declining all responsibility for losses which the traders might suffer from the famished crowds.

A chart of Bosaso and its small harbour (which affords anchorage for sambuks) was constructed in 1906 by Marchese Giulio Santasilia, a lieutenant in the Italian Navy, commanding the squadron of sambuks stationed off the coast of North Somaliland. This chart has since been published by the Hydrographic Institute.

About four hours south-east of Bosaso, on the slope of the El Mascate mountains, is a fresh-water spring called Bio Kulul.1 Usually it is lukewarm, but at certain seasons the temperature becomes so high that, if the natives can be believed, it is impossible to put one's hand into it.

Leaving Bosaso by a path which runs at no great distance from the shore, we find Ras Al Hamar (the Red Cape) at a distance of about to miles. The coast then runs E.N.E. for about 18 miles as far as Ras Hantara $\left(49^{\circ} 3^{8} 8^{\prime} \mathrm{N}\right.$. by ${ }_{1}{ }^{\circ} 27^{\prime}$ E.), a massive and majestic headland, ending in procipitous cliffs about 5,000 feet high.

Between Ras Al Hamar and Ras Hantara are two villages, not very far apart, Baad and Burgaban, both belonging to the Deshisha tribe. Their united population amounts to between 200 and 300 . The most important trade is in frankincense and fish. Three hours farther on is Burd, inhabited by some 150 people of the Jambel tribe. Their principal export is honey, which is here of excellent quality. Burd is on the left bank of a small torrent; three large trees a short distance from the beach make a good landmark.

Ten or twelve kilometres from Burd we come to Kandala, so called from a dense thicket of Kanda" trees between the village and the sea. The founding of this place is connected with the following incident in the history of the Sultanate :-

Saliban, of the line of the Mijjertein Sultans, married a woman of the Dir tribe, by whom he had four sons: Ali, Mahmud, Ismail, and Omar. The two first-named were

1 Somali for "bot mater."

- I bave been umble to find ang confirmation of the statement made by Revoil, $\mathrm{n}$ his Valls an Damer, as to these trees; vir, that the natives have a tradition that any one who breals a bennch of one of them will in the coarie of his life incer some cerious minfortune. I believe that, as not infrequently happens, the atory was simply tevented by Revoil's interpreter in order to excite his interest. 
twins, and some doubt as to the priority of birth between them led to a disputed succession. Saliban, not knowing whicb side to take, and being unwilling to displease either, one day sent Ali with a large number of camels to a deep well called Tog Dero. Ali, on his arrival, was unable to draw water, and, having tried in vain to contrive some means of overcoming the difficulty, returned to his father with the camels, and told him that he had found it impossible to water them at such a well. Saliban then entrusted the task to Mahmud, who, on seeing the depth of the well, killed a camel, made a rope from half its hide, and a waterskin of the other half, and thus succeeded in watering the rest of the herd, which had gone for some time without drinking. Mahmud then returned home, and his father welcomed him with great joy, and perceiving that he possessed greater intelligence and initiative than his brother, nominated him as his successor. Ali and his adherents, however, protested against this decree, thinking that the test was insufficient to decide a matter of such importance.

One morning, therefore, Saliban had recourse to another expedient. Calling Ali and Mahmud, he told them to go to a tree at a short distance from the place where they were then living, to sit down under it, and to wait without moving, till he should come.

The twins having reached the tree, Ali sat down in the shadow (which, of course, at that time of day was on the western side), and Mahmud in the sun, so that when Saliban arrived towards sunset, he found Ali sitting by himself in the full glare of the sun, while Mahmud was in the shade and surrounded by a great number of people, who were waiting for Saliban, and, quite ignorant of his intentions, had naturally chosen the shadiest spot to sit in.

Saliban then, finding more and more how superior Mahmud was in astuteness and intelligence to his brother, said: "Mahmud shall succeed to the Sultanate, because the people are with him; and woe to those who shall oppose him "

After Saliban's death, Mahmud was proclaimed Sultan, but the country was never at peace, owing to the continued raids of $\mathrm{Ali}$ and his followers. The feuds handed down by them to the next generation have become more and more 
deadly down to the present day. One of the most striking incidents of this strange contest during the last century was the assassination by a clansman of the Ali Saliban, of Sultan Mahmud, father of Osman Mahmud, the present Mijjertein chief.

At the time of Sultan Mahmud's assessination, his son Osman was a child of five or six, and the Ali Saliban, hoping to instal as sultan Ismail Muhammad, a direct descendant of Ali Saliban, fixed the capital at the place now called Kandala, so as to concentrate there the whole trade of the Mijjertein country. But the murdered man's brother, the crafty and warlike Nur Jama, assumed the regency, and succeeded in checking the ambitious designs of the Ali Saliban. These, to this day unwilling to submit to any restraint whatever, do not recognise the authority of the present Sultan, nor do they pay any tribute. They are unwearied in their efforts to secure the largest share of the trade, at the expense of the other tribes.

At Kandala there are six forts, one of which belongs to the Bahadir. All bear the marks of the guns of the Italian cruiser Governolo. Seven years ago this vessel anchored off Kandala with the intention of inviting the chief of the country to come to Bosaso, in order to take part, with other chiefs, in a discussion intended to promote the pacification of the country. Interpreters were sent ashore, but were threatened with death by the inhabitants uniess they immediately returned to the ship. As they were embarking, they were twice fired on, with the result that the Governolo directed several well-aimed shells at the village.

The presant chief of Kandala is Muhammad Ismail, a youth of 18 , who also claims the Sultanate of the Mijjertein.

Kandala has no water whatever, and that which the inhabitants have to fetch from Bander Kor is brackish. Nevertheless, they are strongly attached to their country, which is the only outlet to the sea possessed by the important tribe of the Ali Saliban.

Bander Kor, called by the natives Botiala, is nine miles from Kandala, on the left bank of the Tog Wen ("great river "): It is a very ofd village, about two hours' march 
from the coast, and almost hidden by the hill on whose opposite slope Kandala lies, so that very little of it can be seen by anyone arriving by sea. Botiala is inhabited by the descendants of the brothers of Mahmud Yusuf, chief of the Mijjertein, who is said by tradition to have been restless and overbearing, and to have made war on his nine brothers, who were trying to acquire land on their own account. Having defeated them, he granted terms of peace on condition of their giving up all their possessions to him and retiring to Botiala. These nine men were: Hersi Yusuf, Samantar Yusuf, Soyarmarki Yusuf, Nur Yusuf, Ismail Yusuf, Fahia Yusuf, Muhamad Yusuf, Musa Yusuf, Aden Yusuf.

Within the last few years the son of Hersi Yusuf was still living as chief of this district. After his death, the various families were unable to agree on the choice of a successor, so that each of them kept its own chief, and at present there is no unity whatever in the direction of affairs.

The river, whose bed is nearly always dry, at its mouth forms a fine inlet, where sambuks can enter and be beached at high tide. At certain seasons of the year numerous vessels of this class from all parts of the Mijjertein country come to Botiala for repairs, the keels being scraped and then smeared with a mixture of tallow and lime, which keeps the planking in good condition at a relatively small cost.

Durbo is about 30 miles, over difficult and dangerous paths, from Bander Kor. This place is full of sad associations, as it was here that a brave officer of the Italian Navy-Lieut. Carlo Grabau, commanding the armed dhow Antilope-met his death. 'The chiefs of the place, on receiving his intimation that they were to hoist the Italian flag-as, in fact, Sultan Osman had ordered his people to do on the arrival of any vessel whatever-refused to do so unless he showed them the letter from Sultan Osman which he carried, declining to believe his word. Indignant at such an affront to his word of honour as a soldier, he opened fire after a three hours' ultimatum, and received in reply a volley of musketry from the shore. Poor Grabau, struck below the right eye by a Gras projectile, expired on the morning of December 15th, 1903, with his country's name on his lips. The Antilopo 
at once weighed anchor for Bosaso, and on arriving there was ordered by the commander of the sambuk Gassella, stationed off that place, to convey the unfortunate officer's body to Aden, and report the occurrence there without loss of time.

A few hours after the Antilope's departure, a British cruiser, the Mohawk, on her way to the east coast of the Protectorate, anchored at Bosaso, and her captain, Commander Gaunt, no sooner heard of the disastrous incident than he repaired to Durbo to demand satisfaction in the name of the Italian Government. Landing with a bost's crew, Commander Gaunt was forced to retreat, having sustained a dangerous wound in the right thigh, and lost one manJohn Stanton, a marine, killed by an arrow poisoned with wabayo.1 After his recovery, Commander Gaunt had the silver medal "For Valour" conferred on him by the Italian Government. His companions in this hazardous enterprise were Lieuts. Frank Powell and Morris E. Cochrane, and Fleet-Surgeon Charles S. Facey.

Of the inhabitants of Durbo, there were killed in this fight Ali Issa, chief of the village; Mahmud Issa, Musa Haji, and Mahmud Yusuf. The first and second belonged to the Rer Farah Mahmud, the third to Rer Guled Mahmud. and the fourth to Rer Samantar Mahmud. All these three rer (subtribes) are descended from Bellelcasse, one of the wives of Sultan Mahmud Yusuf. The present chief of the place is Nur Gofod of Samantar Mahmud.

There are four forts, all dismantled by the guns of the Italian frigate Galileo, which, after the visit of the Mohawk, descended on Durbo to inflict condign punishment on its inhabitants. At present the site is almost deserted, the people having migrated elsewhere. The only source of income now open to them is the export of frankincense.

The coast between Durbo and Bander Meraya is hilly and precipitous, and, therefore, devoid of villages. About four miles west of Meraya the majestic bulk of Jebel Meraya rises to a height of about I,300 metres (about 4,200 feet). This mountain is the starting-point of the Karum Hills, which

\footnotetext{
1 The juice of the tree Acocanthers wabosen.
} 
surround the country in the shape of a horse-shoe. There is nothing of importance to note as to the foundation of Meraya nearly 200 years ago. It belongs to the Bahadir, and is inhabited by about 400 people of the Osman Mahmud subtribe. There are four or five forts. The country is prosperous, trade is sufficiently developed, and the incense of the Aromata peninsula is exported in great quantities. There is no supply of good water, which has to be fetched from the Aren spring, four miles from the village.

I went to see it, starting from the beach between Ghersa and Meraya. I ascended the Karuma Hills, where I found talc and granite in fairly large quantities, and reached the spring, which the natives have drawn off in irrigation trenches so as to water some small plots of ground, which they cultivate in very primitive fashion. The quantity of water issuing from this spring is at the rate of nearly half a litre per second. Being in need of water on board, we procured some to bring back with us, and found on arrival that it had acquired a reddish tinge through dissolving the substances used for lubricating the water-skins in which it was carried. When filtered, it was found excèllent for drinking purposes.

The chiefs of Meraya are the kinsmen of the late Nur Osman.

Leaving Meraya and travelling almost due north, we come to Garsa, and shortly after to Gasheli, unimportant villages, inhabited by some of the Osman Mahmud, who are employed in fishing. The two villages together amount to about 70 huts. Sambuks anchor here in order to cut firewood.

Still keeping northward, and skirting a low shore, we come to Bander Filuk, which has about 100 huts and 4 forts, built by the Bajagub people. Here an inlet of the sea forms a basin known as the Kor, containing about a fathom of water at high tide. On its inner side is a small village called Habo. Sambuks are beached here, after being got across the bar at the entrance, in order to have their keels scraped. The country round is quite level for a considerable distance. The natives use the Kor for a very primitive kind of salt-making, and I am disposed to agree with what Robecchi-Bricchetti says in his Paese degli 
Aromi, as to the possibility of transforming it and its surroundings into a vast salt-work, which would be extremely profitable. In my opinion, the inhabitants and Sultan Osman Mahmud himself could easily be induced to grant the ground for this purpose. It would certainly be necessary, first, to make it quite clear to them that by so doing they would be improving the economic state of the country, while an annual payment by way of rent might be made to the Sultan, with gratuities (also annual) to the local headmen on condition that they should in no way interfere with the works.

North of Bander Filuk is Ras Filuk, a majestic headland stretching far out to sea. It is well worth while to land either at Filuk or at Alula, a village about five miles east of the Cape, consisting of 200 huts and three large forts, one of which has been dismantled. Its inhabitants belong to the Suakron tribe, and are subject to Yusuf Ali, Sultan of Obbia, who has under his jurisdiction the tract of coast extending from Ras Filuk and Ras Bua, still further to the east of Alula. The chief of the place is a decrepit old man, Ali Samantar, as loyal to our rule as can be expected of a Muhammadan Somali who sees his country occupied by the infidels. In this part the country belonged to the Sultanate of the Mijjertein, but in the course of the fighting which resulted from quarrels between old Nur Osman (guardian of the present Sultan during his minority) and Yusuf Ali, it passed into the possession of the latter, who, desirous of further conquests, started with a number of armed warriors in several dhows for the east cosst of the Mijjertein country, and, having got wind of the fact that he might make a fortune in the neighbourhood of Benadir, landed near Obbia, where, after various skirmishes, he established himself as chief of the place, and marked out the boundaries of his new domain.

At Alula, as at Bander Filuk, the sea forms a wide and shallow inlet, the opening of which is partly closed by a low sand-spit which defends the basin from the fury of the north-east monsoon. Here, too, it would be advisable to establish salt-works-the more so, as all the country round is excedingly flat, and also to construct a harbour, which might easily be done- by dredging the Kor, The Tog 
Galweni, a torrent of slight volume, flows into this basin. From Ras Alula to Guardafui, the coast runs E.S.E.

Having rounded Ras Alula, we reach Moya Bolek, two hours' walk from the headland. There is no sign of inhabitants here, except twenty-three palms; but the place is known to all coasting skippers, as excellent fresh water can be obtained by digging down to the depth of a yard, at a distance of about 100 yards from the beach.

Ras Bua, a short distance further on, is the beginning of an uninterrupted series of mountains which, falling in precipitous cliffs to the sea, end in the massive headland of Cape Guardafui, which I should prefer to call Capo della Nebbia (Misty Cape), never having had a clear view of it on any of the numerous occasions when I have been in its neighbourhood. About half-wdy between Ras Bua and the Cape, in a slight incurving of the mountains, lies Bereda, the former residence of Sultan Osman, with a fort belonging to that chief, which was bombarded by the Volturno in 1906, after he had refused at Hafun to render homage to our nation.

In 1872 a boat's crew belonging to a British man-of-war, having landed to get water, were murdered by the natives. The perpetrators of the outrage were beheaded, and the village burnt. This at present consists of some 100 huts. The people are miserably poor, the only trade being in fish.

Communication between Bereda and Damo, lying further east, is somewhat difficult. At low tide a narrow path connects the two places, but at high water the one can only be reached from the other by boat. Damo and Olok are two groups of about forty huts each, about a mile apart, and situated on the sandy slope of the coast range, which here abruptly curves back from the shore. These villages belong to Sultan Osman; the people are very poor, and eke out a living by fishing and trading in goods plundered from wrecks on the east coast, between Ras Asir (Guardafui) and Shenarif. I remember that the native sailors on board the Antilope, who, with the carelessness of their race, had never thought of providing themselves at Aden, before starting on the cruise, with thick clothing for the cold nights which are not infrequent at sea, here had the opportunity of buying from the natives 
great coats, coats and trousers of every kind and every colour, and more or less ornamented with gold and silver lace. All these things came from a French vessel, the Chodoc, which was wrecked on that coast a few years ago, and whose passengers-mostly belonging to the Foreign Legion-had thought fit to leave behind the greater part of their kit. It was, indeed, curious to the crew dressed in these various uniforms. One of them presented a grotesque figure, with a turban on his head, a cotton vest, a black overcoat, a loincloth, and bare feet!

A little beyond Olok rises the majestic promontory of Guardafui, where these many years past a lighthouse has been projected, though up till now the only ascertainable result of these projects has consisted in words and promises. The inhabitants are violently opposed to the idea, seeing themselves about to be deprived of a very profitable source of income, and Sultan Osman himself, being the person principally interested, is the head and front of the opposition. Tradition states that on the summit of the headland lives a santon praying day and night for the shipwreck of the infidel on that iron-bound coast !

Between September Ist, 1906, and March 31st, 1907, the imports into Aden from the ports on the North Somaliland coast, consisting of incense (several qualities), gum, hides, and other produce, reached a total value of $1,036,036.10$ Italian lire, while cotton fabrics and other goods were exported to the value of $762,206.90$ lire.

\begin{tabular}{|c|c|c|c|c|c|c|c|}
\hline Parte. & & & Incenace. & Hiden. & Other goodi. & $\begin{array}{l}\text { Total to } \\
\text { Ropoes. }\end{array}$ & $\begin{array}{l}\text { Equivalent } \\
\text { in Itritien Lire. }\end{array}$ \\
\hline 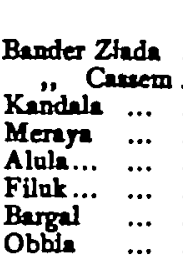 & $\begin{array}{l}\cdots \\
\cdots \\
\cdots \\
\cdots \\
\cdots \\
\cdots \\
\cdots\end{array}$ & $\begin{array}{l}\ldots \\
\cdots \\
\cdots \\
\ldots \\
\ldots \\
\cdots \\
\ldots \\
\ldots\end{array}$ & $\begin{array}{c}\text { Re. } \\
21,608 \\
101,336 \\
14,006 \\
8,128 \\
11,172 \\
11,895 \\
2,017\end{array}$ & $\begin{array}{r}\text { Re. } \\
43,095 \\
130,690 \\
7,905 \\
430 \\
1,720 \\
105 \\
1,640 \\
227,257\end{array}$ & $\begin{array}{r}\text { Rs. } \\
2,770 \\
7,200 \\
285 \\
425 \\
5,280 \\
507 \\
228 \\
9,644\end{array}$ & $\begin{array}{r}67,473 \\
239,316 \\
22,196 \\
8,983 \\
18,172 \\
612 \\
13,763 \\
238,918\end{array}$ & $\begin{array}{r}114,704 \cdot 10 \\
106,837 \cdot 20 \\
37,733 \cdot 20 \\
15,271 \cdot 10 \\
30,892 \cdot 40 \\
1,040 \cdot 40 \\
23,397 \cdot 10 \\
406,16060\end{array}$ \\
\hline Totals & $\ldots$ & ... & 170,162 & 412,842 & 26,429 & 609,433 & $1,036,036 \cdot 10$ \\
\hline
\end{tabular}


The Report on the Trade and Navigation Returns of Aden registers for the period between July, I906, and July, 1907, imports from the "Independent Somali Ports" as amounting to Rs. $1,064,521$, and gives the exports thither at Rs. 86I, 969 , being a total of $3,275,067$ Italian lire and an increase over the preceding year of $417,170.10$ lire.

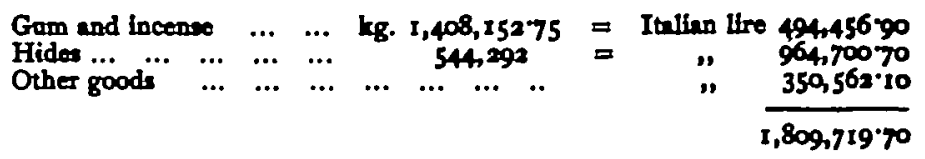

$$
\begin{aligned}
& \text { Cotton fabrics ... } \ldots . . . \quad \text { m. } 1,005,266 \cdot 598=\text { Italien lire } 299,240 \cdot 80
\end{aligned}
$$

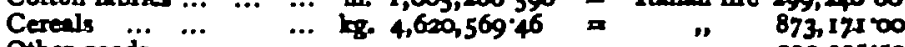

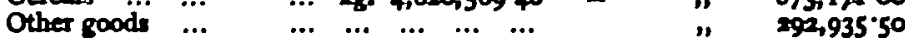

$$
\begin{aligned}
& 1,465,34730
\end{aligned}
$$

These figures are for the port of Aden only, but in order to have an approximate total of the import and export trade of Northern Somaliland, we must take into account the trade carried on by sambuks with Maskat and Makalla on the Arabian coast, Bombay, and Zanzibar. Including this, we may, on the lowest estimate, without fear of contradiction, fix the value of the goods imported and exported in a year at an average of $5,000,000$ lire.

Owing to the work of British Residents in the interior of the Somaliland Protectorate, the greater security of the caravan roads and the improvements in Berbera Hapbour, to the consequent influx of Arab and Indian merchants, and to the shorter distance from Aden, the majority of caravans coming from the interior and the Nogal Valley prefer to take the longer road to Berbera, rather than bring their goods to our ports in the Mijjertein country. I am unable to say what is the value of the trade of British Somaliland, because the statistics available include that of Jibuti and other French ports in a total amounting to $17,000,000$ rupees. The greater part of this sum is derived from the Abyssinian trade, which finds its outlet at Jibuti.

Giulio Baldacci. 